pragMATIZES - Revista Latino Americana de Estudos em Cultura

Dossiê 


\title{
O tríplice feminino: Jesus, Medeia \\ e a identidade do Poeta enquanto uma feiticeira sacrificada
}

\author{
El tríplice femenino: Jesus, Medeia \\ y la identidad del Poeta mientras una hechicera sacrificada
}

The triple feminine: Jesus, Medea

and the Poet's identity as a sacrificial witch

Fábio Gerônimo Mota Diniz'

Palavras chave:

Resumo:

Jesus

Medeia

Poesia

Construído a partir de uma comparação entre as figuras da personagem mítica grega Medeia e do salvador e filho de Deus, da mitologia cristã, Jesus Cristo, o texto pretende apresentar uma faceta possível da figura do Poeta que nomeamos "feiticeira sacrificada". A ideia é propor um topos referencial simbólico a partir do qual se compreenderá o artista, especialmente o Poeta, como uma figura feminina e dotada de especiais poderes sobre o cosmos, cujo sacrifício a leva a uma ascensão. Nessa ascensão se revelam uma série de símbolos e imagens ligadas ao universo da mulher enquanto mãe, estrangeira e feiticeira, que operam como motores fundamentais do seu fazer poético, derivado dessa crise instaurada na identidade do eu-criador diante de seu martírio. Assim, partindo dessa nossa análise dos dois personagens arquetípicos, faremos a proposta de uma percepção da feiticeira sacrificada como um dos possíveis arquétipos identitários desse Poeta posto diante do sofrimento. 


\section{Resumen:}

Construido a partir de una comparación entre las figuras de lo personaje mítico griego Medea y el Salvador y el hijo de Dios, de la mitología cristiana, Jesús Cristo, el texto tiene la intención de presentar una posible vista de la imagen del poeta que nombramos "bruja sacrificio." La idea es proponer un tópos referencial simbólico de que el artista, sobre todo el poeta, será entendido como una figura femenina y dotado de poderes especiales sobre el cosmos, cuyo sacrificio conduce a una ascensión. En esta ascensión se revelan una serie de símbolos e imágenes vinculadas al universo de la mujer como madre, extranjero y bruja, que actúan como fuerzas fundamentales conductor de su obra poética, derivados de esta crisis en la identidad del creador frente a su martirio. Así, a partir de nuestro análisis de los dos personajes arquetípicos, propondremos una percepción de la hechicera sacrificada como uno de los arquetipos de la posible identidad de esta poeta frente al sufrimiento.

\section{Palabras clave:}

Jesus

Medeia

Poesia

\section{Keywords:}

Jesus

Medea

Poetry

\section{Abstract:}

Built from a comparison between the figures of the Greek mythical character Medea and the savior and son of God, from Christian mythology, Jesus Christ, the text intends to present a possible sight of the Poet's image we named "sacrificial witch." The idea is to propose a symbolic referential tópos from which the artist, especially the Poet, will be understood as a female figure and endowed with special powers over the cosmos, whose sacrifice leads to an ascension. In this ascension are revealed a series of symbols and images linked to the universe of the woman as mother, foreigner and witch, who act as fundamental driver forces of her poetic work, derived from this crisis established in the identity of the creator in the face of her martyrdom. Thus, starting from our analysis of the two archetypal characters, we will propose a perception of the sacrificed sorceress as one of the possible identity archetypes of this Poet in the face of suffering. 


\section{O tríplice feminino: Jesus, Medeia \\ e a identidade do Poeta enquanto uma feiticeira sacrificada}

\section{Introdução}

Em artigo outrora publicado, partimos de uma comparação entre as figuras do herói mítico grego Orfeu e do anjo caído da mitologia judaico-cristã Lúcifer, para apresentar uma faceta possível da figura do Poeta que coincide com a do anjo-caído, tendo em vista um tópos referencial simbólico a partir do qual se compreende 0 artista, especialmente o Poeta, como um herói que, rebelado contra certa instância de poder, sofre uma queda ocasionada por um erro inescapável. Àquele momento propusemos uma leitura incompleta, visto que para o fechamento de um sistema simbólico, surgira uma demanda pela instância dialógica complementar, ou seja, das figuras que divergiriam do sistema proposto. A urgência de complementação surge, ainda, do notável trecho que destacamos de poesia do brasileiro Carlos Drummond de Andrade, ao fazer-nos enxergar pelo famoso "Poema de sete faces" outra faceta de Jesus Cristo:

Meu Deus, por que me abandonaste se sabias que eu não era Deus se sabias que eu era fraco (ANDRADE, 2013, p. 11)

Apontamos a explícita referência do Poeta ao clamor de Jesus Cristo que, diante de destino funesto destino da crucificação, afirma no Evangelho segundo São Marcos (15:34) e também segundo São Mateus (Mt. 27:46)":

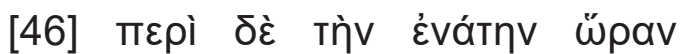

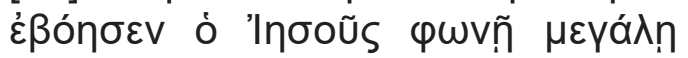

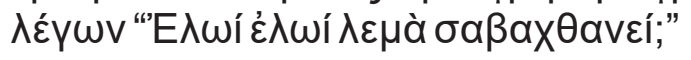

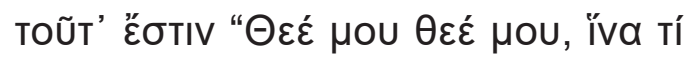

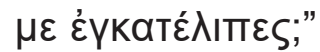

Acerca da nona hora, exclamou Jesus em voz alta, dizendo "Eloí Eloí, lemá sabakhthaneí?", isto é, "Meu Deus, meu Deus, por que me abandonaste?"

A referência, no texto grego, 'E $\lambda \omega$ í

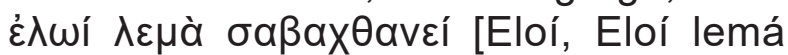
sabakhthaneí] é uma transcrição do hebraico, associada ao Salmo 22, que diz "נינתקבש אמל יהלא יהלא" [Eli Eli lama azavtani]. Cristãos tradicionalmente identificam este salmo como um prenúncio da crucificação do messias e, de tal modo, de seu martírio em prol da humanidade. Propusemos, no texto em questão, observar uma ambiguidade construída por Drummond no poema, pois, sendo o poema de um gauche, este anjo torto poderia igualmente ser, Lúcifer, que fora punido por Deus justamente por não poder ser ele mesmo Deus. De tal modo, espelha-se tanto o filho de Deus e salvador da humanidade quanto o anjo caído,movimento que, como observamos, por último, encontra lugar no próprio Apocalipse, quando Cristo se equipara à Estrela da Manhã (KELLY, 2008, p.9), símbolo luciferiano por excelência.

A despeito de possíveis outras interpretações, tínhamos como objetivo a leitura simbólica imagética do duplo Lúcifer-Orfeu como sendo um ícone para a imagem do Poeta enquanto essa figura caída, que de sua queda faz a arte. E, de tal modo, abre-se o mesmo caminho da duplicidade judaico-cristã-helênica em relação ao aproveitamento da contraparte imagética de Orfeu: a feiticeira Medeialv.

Para implementar essa leitura, assumiremos uma perspectiva similar à assumida no outro texto, fazendo uma analogia entre as figuras a partir de suas constelações simbólicas, ou seja, 
dos elementos imagéticos que dialogam entre si. Como observa Gilbert Durand, "os símbolos constelam porque são desenvolvidos de um mesmo tema arquetipal, porque são variações sobre um arquétipo (DURAND, 2012, p. 43)". No caso, propusemos naquele texto um arquétipo, o do Poeta enquanto anjo/herói caído, e concluímos que "a poesia como ato de desobediência que revela, ao mesmo tempo, uma angústia existencial". A partir dessa premissa, a reflexão que dialoga Medeia e Jesus deve, da mesma forma, desenhar uma relação analógica/alegórica entre símbolos que constelem em favor de um tópos. Assumimos, de início, as características de Medeia que convergem na sua representação dentro da literatura grega: o feminino, o estrangeiro e o feiticeirov ${ }^{v}$. Nesse sentido, precisamos analisar essas três premissas para entender se há a possibilidade do contraponto ao binômio Orfeu-Lúcifer em Medeia-Jesus. Como o título do artigo propõe, a natureza mágica será o ponto chave, mas não abandonaremos as outras perspectivas pois, de fato, toda a construção dessas personagens pode ser encarada como um diálogo simbólico religioso-poético e, ademais, configurar um novo tópos.

\section{Feminina}

A imagem que temos de Jesus Cristo - homem caucasiano, geralmente louro e de olhos claros, com cabelos longos e lisos e barba -, consagrada pela iconografia tradicional, vem sendo muito questionada em tempos recentesvı. Porém, em geral, há pouco a se questionar no que diz respeito à percepção de seu gênero, masculino. A despeito de questionamentos sobre sua relação com mulheres - essencialmente Maria Madalena - popularizada seja por teóricos conspiratórios, seja pela literatura popular. E é claro que não parece haver motivos para se questionar sua representação enquanto homem.

Em 2015, a atriz Viviany Beleboni causou polêmica durante a $19^{a} \mathrm{~Pa}-$ rada do Orgulho LGBT, em São Paulo, ao aparecer crucificada, encenando o martírio de Jesus Cristo que é o pilar da religião cristã. A polêmica deriva, essencialmente, do fato de Viviany ser transexual, e de sua encenação ser um ato de protesto contra a violência constante contra grupos LGBT. Utilizando-se da iconografia associada à figura símbolo do cristianismo, ela pretendia, em suas palavras, usar "as marcas de Jesus, que foi humilhado, agredido e morto. Justamente o que tem acontecido com muita gente no meio GLS, mas com isso ninguém se choca (DANTAS, 2015)". A cena apresentada por Viviany dialoga particularmente com a peça $O$ EvangeIho segundo Jesus, rainha do céu, de Jo Clifford, na qual a autora propõe a ideia de um Jesus que volta ao mundo como transexual. Assim como o protesto de Viviany, a peça de Clifford foi alvo de severas críticas já na sua primeira apresentação, em 2009, e não foi diferente quando apresentada, em 2016 e 2017, sob a direção de Natalia Mallo. Por fim, podemos ainda mencionar entrevista feita com a primeira pastora transexual da America Latina, Alexya Salvador, que questiona o gênero de Jesus para defender sua posição enquanto sacerdotisa, afirmando que "Jesus Cristo foi o primeiro homem trans (DECLERCQ, 2017)". Ela parte da trindade, o Pai, o Filho e o Espírito Santo, para apontar que, se Deus enviou seu filho para a terra ele, Jesus, "tinha o gênero divino, correto? Então, quando ele desceu para a terra ele passou a ter o gênero humano". Nessa proposição, Jesus, Deus e toda divindade seria, em suma, agênera, ou ao menos a noção do que é gênero para as divindades seria algo distante de nossa noção de gênero. 
Claro que pode soar, ao leitor interessado em um texto acadêmico, que nossas interlocutoras não serviriam de fundamento para propor uma visão diversa do gênero do filho de Deus. $E$, de fato, não é o que esse artigo propõe, em si, mas sobre o foco do texto nos debruçaremos depois. O que propormos, aqui, é uma justificativa para se pensar além da iconografia e, claro, não ignorar a implicação política dessa proposta. Não obstante, o interesse maior de todas as interlocutoras listadas acima é defender a presença do corpo político da trans, renegada que é ao espaço do "anormal", e para tanto usar a figura sacra de modo blasfêmico serve ao propósito provocativo. O que une Beleboni, Clifford e Salvador é a disputa política pela participação de seus corpos no contexto de uma sociedade que ainda mata as transexuais apenas por serem. E nisso, claro, este texto provoca, também, ao se iniciar com tais discursos - as mencionando, defendemos suas presenças e nos alinhamos politicamente a elas. No entanto, é apenas essa a perspectiva possível quando se fala do gênero de Jesus?

Não é, e uma leitura distante temporalmente, mas talvez próxima contextualmente, é a de Juliana de Norwitch, anacoreta e mística inglesa que viveu no século XIV. Partindo de trecho do livro de Isaías, 49: 15, em que o profeta compara o amor de Deus ao de uma mãe pelo seu filho, Juliana apresenta, em seus escritos, uma imagem de Jesus que o aproxima de uma mãe, e a relação mística real que se pode ter com ele seria a mesma entre um filho e sua mãe.E, segundo Bynum, essa não seria a única leitura que aproxima as figuras divinas da figura da mãe; ela apresenta ao menos oito autores cristãos, todos homens, do século XII. Para ela, a comparação tem fundamento em dois aspectos fundamentais:
Em primeiro lugar, as imagens assumem certos estereótipos sexuais isto é, elas mostram que, para esses escritores religiosos, certas características de personalidade foram vistas como femininas, e outras características como masculinas. Ao longo desses textos, gentileza, compaixão, ternura, emoção e amor, nutrição e segurança são rotuladas como femininas (ou "maternas"); autoridade, julgamento, comando, rigor e disciplina são rotulados como masculinas (ou "paternas"); instrução, fertilidade e criatividade estão associadas a ambos os sexos (seja como geração ou como concepção). [...] Um segundo padrão une essas imagens o que é tão óbvio quanto o primeiro. Tanto em referências a figuras de autoridade terrenas quanto em referência a Deus, a imagem materna é uma imagem de dependência, ou união ou incorporação. Os seios e a nutrição são imagens mais frequentes nesta literatura do que a concepção e o parto. E onde o nascimento e o útero são imagens dominantes, a mãe é geralmente descrita como a que concebe e carrega a criança no seu ventre, não como aquela que expulsa a criança no mundo, sofrendo dor e possivelmente a morte para dar vida. Concepção e parto, como a amamentação, são, portanto, imagens principalmente de fertilidade, retorno ou união, segurança, proteção, dependência ou incorporação, não imagens de alienação, sacrifício ou emergência no sentido da separação. As referências a Deus como mãe geralmente ocorrem, não no contexto de castigo dos pecadores ou elaboração do abismo entre humano e divino, mas sim como parte de uma imagem geral do crente como criança ou iniciante, totalmente dependente de um Deus amável e amoroso (BYNUM, 1977, p. 269 ${ }^{\mathrm{VII}}$ ). 
O que Bynum aponta é fundamental para que compreendamos a natureza ambígua, mesmo para esses antigos escritores cristãos, da divindade. Seja enquanto Deus, seja no corpo de Cristo, encontramos a presença de características que apontam para uma forte presença do feminino em mais de uma dimensão, mesmo se dispensadas as percepções estereotipadas e misóginas desses escritores.

Acrescentamos, ainda, o destino de Cristo, que é entregar seu corpo em sacrifício. Antes mesmo de ser definitivamente sacrificado, Cristo se oferece a seus apóstolos (todos homens) em banquete do qual todos se alimentam de seu corpo e sangue. Essa narrativa, que funda o evangelismo, apresenta a imagem de um sacrifício alimentar em que o sacrificado é um ser que, mesmo não sendo um animal, possui uma natureza diversa da humana, mesmo que a um humano se as- semelhe. A comunhão do corpo de Cristo se dá enquanto alimento e, não por acaso, temos matéria sólida e líquida: como a mãe que é, Cristo se doa a seus filhos e os alimenta. É pela nutrição que acontece a união, a comunhão, e como aponta Bynum essa comunhão recupera a imagem desse Deus amoroso e maternal da qual Cristo é o símbolo mais caro.

E é o aspecto maternal um dos mais marcantes do feminino no mito de Medeia. Segundo a fonte tradicional, a tragédia de Eurípedes, quando traída por Jasão, Medeia decide vingar-se assassinando seus próprios filhos. O ato choca, obviamente, pelo peso que existe em uma mãe vitimar sua própria prole, e pela natureza da decisão estar atrelada à vingança, o que poderia supostamente transformar o crime em um ato praticado por motivo torpe. Nesse sentido, cabe retomar as palavras de Medeia na obra do tragediógrafo grego:

Redireciono a fala neste ponto -

Arraso o alcácer de Jasão e sumo, pela senha fatal contra os meninos que mais amo no mundo, sob o crime que mais que nenhum outro agride o pio: o riso do inimigo fere o íntimo.

A vida avulta? Avilta, se há vacância de lar, pátria, refúgio contra os sujos. Que erro crasso deixar o paço pátrio, cair na logorreia de um helênico, o qual, se deus quiser, será punido! Não mais sorri aos jogos dos meninos, nem cria outra linhagem com sua ninfa: meus fármacos fatais hão de matar terrivelmente a terribilíssima.

Não queiram ver em mim um ser fleumático ou flébil. Tenho outro perfil. Amor ao amigo, rigor contra o inimigo; eis o que sobreglorifica a vida! 
De certo modo, mesmo que a atitude seja fruto de ciúmes e uma vingança contra a traição, esta não está restrita ao fato de Jasão se casar com outra mulher, mas à promessa feita a Medeia. Sua postura diante do ato depende muito mais do seu status como estrangeira que confiara ao herói seu futuro e, por ele, abandonara tudo que Ihe era sagrado, que de ciúmes propriamente dito. Antes, porém, de partirmos para a análise desse aspecto, ainda precisamos abordar, de modo comparativo, a natureza feminina de Jesus e Medeia.

Medeia, assim como Cristo, é mãe, como observamos. No entanto, ao invés de sacrificar a si em prol de seus filhos, ela sacrifica os filhos em prol de sua honra manchada, em um ato condenável. Porém, claro, trata-se de um sacrifício se considerarmos o status do amor materno como algo inalienável e, nesse sentido, ambas, Jesus e Medeia, são mães que sofrem a dor de se sacrificarem, quaisquer os motivos. Além disso, tendo em vista que Jesus é, ao mesmo tempo, filha e o próprio Deus, podemos considerar sua premeditada entrega como um sacrifício da mãe-Deus, e é sob essa ótica que muitas vezes é feita a lamentação religiosa que conduz à compreensão da comunhão como um ato de remissão dos pecados. Deus entregou sua filha, Jesus, para ser morta em prol da humanidade - que, por seus atos funestos, já havia sido condenada antes, pelo dilúvio -, e esse seria um ato benevolente, de amor. De certo modo, mesmo que condenável, o ato de Medeia também é o ato amoroso, mesmo que seja do abandono do amor - "Amor/ao amigo, rigor contra o inimigo;/eis o que sobreglorifica a vida!". Se eles não têm consciência do crime da mãe, os filhos de Medeia, como Jesus, não possuem livre-arbítrio para negarem seu destino.

Além disso, o ato de assassinato dos filhos, considerados como extensão do corpo feminino, também é um ato de sacrifício. Medeia entrega parte de si, seu próprio sangue, à morte:

Está traçado, amigas: mato os filhos e apresso a fuga. Não existe um ser - um ser somente! - que suporte ver o braço bruto sobre os seus. Não tardo: o fim dos dois se impõe e a mãe os mata, se é isso o que há de ser. Ó coração-hoplita, descumprir esse ato horrível, se ananke, o imperativo, o dita? Empunha, mórbida mão, o gládio, e mira o triste umbral de tânatos! Deslembra o amor de mãe, não te apequenes! Na jornada brevíssima de um dia, não te atenhas ao fato de que deles és a origem, posterga tuas lágrimas! Amaste quem dizimas. Funesta a moira mesta. 
Ao dizer, em Eurípedes, “amaste quem dizimas", Medeia entrega seus filhos à morte, como Deus à sua filha Jesus. E não se questiona seu amor, pois a própria Medeia afirma categoricamente que "Não existe um ser/- um ser somente! - que suporte ver/o braço bruto sobre os seus". A despeito de Deus ser questionado por Jesus acerca de seu abandono, sabemos que ela conhece essa dor e a valoriza por outro evento: quando pede a Abraão que sacrifique seu filho, Isaque, por ela. Porém, mãe, ela envia o anjo para que interrompa o ato, visto que percebera no pai a disposição para consumá-lo. A morte do filho, em resumo, é um ato sagrado, de entrega e amor.

Podemos, ainda, destacar a traição como movimento fundamental nas duas narrativas. Medeia e Jesus caminham para seus sacrifícios por serem traídas, ambas, por um homem (Jasão/Judas). A traição de Jesus possui traços de uma relação mais íntima, podemos acrescentar, com o famoso beijo narrado nos evange-

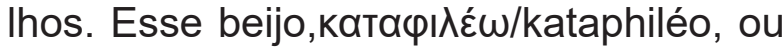
seja, um beijo terno e amoroso, é o sinal de Judas aos soldados de que aquela pessoa era Cristo. Porém, mesmo que o beijo seja um sinal, o evangelho de Mateus chamá-lo de kataphiléo intensifica o ato, dando ares de um amor terno entre os dois, de carinho, e não de dissimulação. De fato, se destilarmos a imagem, temos um domínio da relação amor-traição, tanto em Medeia como e Jesus.

$E$, ainda, é impossível esquecer que um dos dados marcantes e fundamentais da figura de Cristo é justamente o seu nascimento de uma virgem, Maria, a figura central do culto feminino dentro do cristianismo. A virgindade associada à pureza é um dos traços definidores de várias culturas ocidentais, e não é forçoso pensá-la sob a ótica da dominação masculina sobre a mulher, sendo a consumação do matrimônio um ato celebrado como a posse definitiva da mulher por seu esposo.
Em que valha, ainda, a iconografia associada ao ato - o sangramento, a entrega, a união - queremos, contudo, destacar a aproximação que Tereza Virgínia Ribeiro Barbosa faz entre Maria e Medeia:

É tempo agora de abordar a figura de pensamento que nos dirige, o paradoxo que fica claro a partir da antítese que escolhemos no título. Medeia e a Virgem-Mãe Maria. Dois absurdos: aquela, que com sua face sombria e totalitária advinda de uma antiga divindade feminina, gera para matar e aquela outra que, sendo gente comum, mulher virgem, é também mãe de uma divindade. Ela própria, outro absurdo, não chega a ser deusa-mãe, mas é tão-somente mãe da divindade.

Medeia, constituída a partir do poder, se coloca na disputa, na repressão, na neutralização do outro e é por isso mesmo essencialmente autocentrada; a virgem-mãe se coloca num lugar de fronteira ou numa espécie de fusão de condições opostas, de incorporações de diferenças, lugar onde se encontram o dominador e o subjugado (BARBOSA, 2013, p. 6-7).

Escolhida para carregar a filha da divindade, Maria é desprovida de vontade própria - motivação, é bom que se diga, da natureza misógina e opressora de muitos cultos cristãos na lida com as mulheres e seu ato é um "absurdo", como observa Barbosa, posto que não poderia conceber enquanto virgem. Ao ser violada por Deus - aí sim, em sua natureza masculina, representada pelo anjo -, Maria se aproxima das tantas jovens donzelas estupradas por Zeus na mitologia grega. Porém, desde que recebe a sua "tarefa", ela sabe que seu destino é apenas do de receptáculo da rebenta que irá, sacrificada, redimir a humanidade. Apesar de completamente diferentes em seus objetivos finais, destaca-se a determinação de ambas em cumprirem seus papéis, em se entregarem - e a seus filhos. 


\section{Estrangeira}

A que se deve a fúria de Medeia? Flávio Ribeiro de Oliveira, na introdução de sua tradução da Medeia, observa que a origem do sentimento de Medeia não está restrita ao ciúme, como comentamos acima, mas está diretamente relacionada ao conceito grego de timế, "honra", que assume nesse contexto o sentido de "valor atribuído a alguém por seus iguais". Assim ele apresenta a motivação do ódio de Medeia pelos atos de Jasão:

[...] Medeia, neta do deus Sol e filha do rei da Cólquida, fora honrada e respeitada em sua comunidade. Mas fugiu com Jasão, depois de trair seu pai e sua pátria; na fuga, matou seu irmão e cometeu uma série de crimes horrendos - tudo isso por amor de Jasão, para ajudá-lo e para honrá-lo. Ao trair seu país e sua família, perdera irremediavelmente a timé de que fruía na Cólquida. Para ela, não havia possibilidade de retorno, seus atos tornaram inviáveis a volta para casa e a reassunção daquela timé. Medeia sacrificou definitivamente tudo o que tinha por Jasão; de sua perspectiva, Jasão deveria, em troca, atribuir alto valor, deveria honrá-la e fazê-la honrada em Corinto, cidade em que se refugiaram: é um princípio de reciprocidade. Mas ela é frustrada justamente nessa timé a que teria direito: Jasão, em vez de honrá-la, a troca pela filha de Creonte, rei de Corinto (OLIVEIRA, 2007, p. 13).

A reação violenta de Medeia, de tal modo, tem origem na traição de Jasão à sua honra e a seu juramento. É uma relação de troca entre estrangeiros mediada por uma relação amorosa que se sustenta a ação de Medeia. Nesse sentido é inevitável e substancial o fato de que a hospitalidade oferecida a um estrangeiro e a subsequente viagem para longe de sua casa selam o destino de Medeia.
A iconografia do nascimento de Cristo, celebrada anualmente, é amplamente conhecida e dispensa pormenores. A despeito disso, como no caso de Medeia, sobressaem as tópicas da hospitalidade e da viagem: Maria concebe Jesus fora de sua cidade natal, em Belém, em uma manjedoura pois não encontra hospedagem. Ambas, Medeia e Jesus, são estrangeiras quando atingem sua vida adulta e vivem seus sacrifícios e, mesmo que para a segunda a natividade seja menos problemática, seu nascimento é fundamental como elemento de congregação. Além de seus pais, viajam em busca da anunciação do messias os famosos três reis magos, figuras alegóricas representantes do Oriente e que cumprem uma profecia anunciada nos Salmos, 71:11, "E o adorarão todos os reis e todas as nações o servirão'IX". Além disso, a criança é visitada por outros pastores e admirada pelos próprios animais, o que, podemos considerar, demonstraria que nela residiria a comunhão entre todos os seres e todas as nações.

Porém podemos alargar o campo semântico da noção de "estrangeiro", para abarcar outro evento: a ascensão. Medeia, após seus atos trágicos, é levada no carro do sol para os céus; Jesus ressuscita, ao terceiro dia após sua morte, e vai viver ao lado de Deus - ou voltar à sua essência enquanto Deus, se considerarmos que ela é a própria divindade. Nos dois casos, a ascensão tem um papel fundamental se considerarmos sua dimensão imagética. Como aponta Durazzo:

$\mathrm{Na}$ esteira de Bachelard, Gilbert Durand aponta as diferentes valorizações que as imagens ascensionais podem apresentar. Se, por um lado, elas indicam o impulso rumo ao sagrado, o caminho que liga chão a céu é capaz de assumir diversas posturas éticas. Daí que, além da direção do sagrado, a verticalidade também se liga à direiteza moral, à hierarquia - política monárquica, litúrgica ou militar -, ao monoteísmo e às práticas de elevação que entrela- 
çam pureza, castidade, moral e santidade (DURAZZO, 2013, p. 55).

Assim, a ascensão de Medeia/Jesus traz um reencontro da divindade em carne com sua essência divina, ou seja, religa o humano ao divino. É ritualístico esse movimento, com certeza, e impregnado de sagrado - como o é a catábase de Orfeu/Lúcifer. E, se os efeitos dessa ascensão não são os mesmos, são ao menos aproximáveis: Cristo retorna para os céus, ao lado de sua mãe Deus para ser rainha e divindade, enquanto a ascensão traz a redenção de Medeia, que após seu ato de sacrifício não teria mais lugar nesse mundo. De certo modo, em analogia com o aspecto estrangeiro de ambas figuras, Medeia e Jesus são ambas estranhas em relação aos mundos de que fazem parte, seja por serem figuras desafiadoras da ordem, seja por serem ambas detentoras de poderes que extrapolam a naturalidade.

Se considerarmos o caráter de estrangeira, portanto, Medeia e Jesus são consideravelmente diferentes, mesmo que compartilhem certas dimensões imagéticas e simbólicas. Há que se considerar, no entanto, que ambas são descendentes de divindades e sua relação com essas potências - e com outras figuras que podem assumir papel similar, ao menos alegoricamente - encaminha definitivamente nossa análise para o aspecto poético da nossa comparação.

\section{Feiticeira}

Ao agir enquanto sacerdotisa da deusa Hécate, Medeia utiliza-se de phármakon, ou seja, de preparados mágicos e poções, motivo pelo qual no poema Argonáutica, de Apolônio de Rodes, poema épico do séc. III a.C., será chamada de polyphármakon (III, v. 27; IV, v. 1677) "a de muitos fármacos". É por meio desses fármacos que Medeia irá garantir que o herói Jasão conquiste o poder de subjugar terríveis desafios e con- quiste o velocino dourado, seu objetivo na viagem ao lado dos Argonautas. E é com os mesmos fármacos que ela conduzirá à morte Pélias, tio do herói e usurpador do trono de lolco, do qual Jasão seria príncipe, por direito. Por fim, será pela sua habilidade de feiticeira que ela assassinará também o rei Creonte e sua filha Creúsa, futura esposa de Jasão, usando de uma túnica impregnada de seus fármacos.

Jesus pode ser, para todos os efeitos e em larga medida, uma feiticeira. Suas práticas, chamada de milagres, envolvem cura, exorcismo, multiplicação de itens, ressurreição e outros eventos fantásticos. No entanto, Jesus não se vale de phármaka para tal, mas de seus dons derivados de sua descendência divina, o que poderia afastá-lo, em nossa comparação, de Medeia. Podemos manter a comparação, ainda, pois Medeia é filha de Eetes, senhor da Cólquida, e com isso descendente direta do deus sol, Hélio. Essa descendência é evidenciada mais de uma vez ao longo das representações clássicas de Medeia, especialmente com o destaque dado a seu olhar. Em Apolônio, o poder do olhar de Medeia recebe destaque em III, vv. 886-7, quando é dito que as pessoas se afastavam para evitar olhar diretamente para seus olhos; em IV, vv. 727-29, quando Circe, irmã de Eetes e filha de Hélio, portanto, busca identificar seu parentesco com a sobrinha pelo brilho no olhar; e, por fim, quando ela derrota o gigante de bronze Talos, no Canto IV, que a própria Medeia apresenta como um feito individual, de seus poderes apenas (IV, vv. 1654-68).

Por outro lado, Jesus não interage, em nenhum momento, com intenções destrutivas. Enquanto o phármakon no contexto tradicional da feitiçaria de Medeia seria, ao mesmo tempo, remédio e veneno, Jesus utiliza seu dom apenas para a cura, nunca para provocar qualquer tipo de dano mesmo a seus maiores inimigos. É de sua natureza, visto que é a filha de Deus e herda seu amor infinito e incondicional, 
resumido pelo seu mandamento de amar a todos e dar a outra face a um inimigo. Nesse sentido, mesmo que considerássemos como phármaka as atitudes de Jesus, ela não pode ser como tal admitida por não ter essa dupla função, sendo restrita em sua atuação enquanto feiticeira unicamente voltada para o bem, para a cura. Além disso, no capítulo nono do livro do Apocalipse, os feiticeiros, phármakos, são condenados duas vezes, sendo colocados entre aqueles atingidos por uma segunda morte, a condenação eterna da alma, por não se arrependerem de seus pecados.

Assim, por um lado, tanto Medeia como Jesus podem ser observadas enquanto feiticeiras que se valem de sua ascendência divina (Hélio/Deus) para realizar seus milagres/magias. Como feiticeiras, elas desafiam a ordem e fazem uso de suas habilidades para contrariar instâncias de poder (Eetes/Jasão de um lado, Roma do outro), e por isso são condenadas - Medeia, punida com o abandono de Jasão, se torna uma assassina; Jesus, com o destino de sofrer em prol da humanidade, é morta de forma horrenda. E, como um acréscimo fundamental, lembramos ambas ascendem após o sacrifício realizado, igualando-as em sua natureza divina. Porém, por outro lado, o que Jesus faz na bíblia não pode ser considerado phármakon, pois não apenas ele não se vale de itens e combinações de produtos para realizar seus milagres, como estes são condenados pela própria escritura, indicando que se há similaridade aparente, esta se dá tão somente no nível analógico, não diretamente.

\section{A Hécate e as Três Marias}

Mas há uma segunda dimensão da interação com o mundo sobrenatural, muito importante para a compreensão da figura de Medeia, que é sua dedicação ao sacerdócio de Hécate. Essa divindade, como observa Prado, possui uma série de elementos simbólicos aos quais iremos nos direcionar para refletir sobre a persona poética que converge Medeia e Jesus:

Devido à sua identificação com Ártemis, Hécate tomou de empréstimo, num primeiro momento, algumas das funções daquela deusa, por isso, às vezes Hécate era considerada uma divindade lunar e ctônica, o que lhe conferiu, ao mesmo tempo, um poder sobre a vegetação e sobre o mundo subterrâneo (em seu aspecto ctoniano) e sobre as águas do mar (em seu aspecto lunar). Seu culto irá refletir sua dupla natureza, pois, por um lado, ela tomava parte em cerimônias mágicas, por outro, também nos ritos oficiais e familiares. [...]Hécate tinha duas iconografias: a primeira representava-a apenas em uma forma feminina simples e sem atributos particulares; a segunda, sob uma forma tríplice, isto é, possuindo três corpos e três cabeças mescladas entre si, ou apenas um corpo com três cabeças, constituindo uma representação das três fases visíveis da Lua: crescente, cheia e minguante (cf. LAVEDAN, 1931: 496-498; e Ramous, in: TIBULO, 1988: 238) (PRADO, 2011, p. 14, n. 5).

Esta representação de Hécate de três faces, talvez a mais famosa, traz uma série de simbologias que podemos associar diretamente ao feminino, como a relação com a terra, com as plantas e com a lua e suas fases. Atributos associados ao imaginário que circunda a Deusa Mãe, podemos pensá-los em uma chave muito interessante, se nos atermos ao séquito feminino de Cristo.

Maria, a mãe de Jesus, possui em sua simbologia estreita relação com as divindades pagãs que formam o arquétipo da Grande mãe, como observa Flávia Marquetti:

Maria apresenta, enquanto mãe divina, em sua iconografia, os mesmos sím- 
bolos que as deusas pagãs: a maçã, o marmelo, a romã, ou o trigo/cereal, símbolos da fertilidade e fecundidade da terra; a lua crescente, que ao mesmo tempo se liga ao chifre do touro, seu consorte, bem como à foice que o emascula nos rituais de fertilidade e indica o tempo cíclico da colheita; a(s) estrela(s) que caracteriza $(\mathrm{m})$ o solstício de verão e a coroa, geralmente de estrelas, símbolo de sua "realeza", mas também de Ariadne, esposa de Dioniso; a serpente, epifania da grande Deusa Mãe; as rosas brancas de Ártemis e/ou as vermelhas de Afrodite, bem como os lírios consagrados às deusas ctônicas, como Perséfone e Deméter, a Afrodite Negra, ou ainda à Ártemis-Hécate. [...] Mas, dentre todos esses elementos, o seio nu,símbolo primordial da Deusa Mãe, enquanto geradora e nutriz, e omenino, fruto desse poder gerador, são os emblemas da Virgem Mãe,quer seja ela cristã ou pagã (MARQUETTI, 2013, p. 248).

Assim como Medeia, portanto, Jesus é relacionada diretamente a uma figura que representa a divindade do feminino materno. Como observamos, Jesus é também mãe, simbolicamente, e nisso se relaciona com Medeia, cuja maternidade é fundamental ao cumprimento do mito trágico. Há que se salientar, ainda, que Maria compartilha segundo Marquetti uma relação com Ariadne, esposa de Dioniso; enquanto divindade dúbia, trans ou bissexuada, Jesus possui íntima relação com o Deus grego em sua iconografia - o vinho, o duplo nascimento que configuram uma constelação simbólica que Durand (2012, p. 300) analisa, a simbologia do Filho que justifica sua androginia:

O símbolo do Filho seria uma tradução antiga do androginato primitivo das divindades lunares. O Filho manifesta assim caráter ambíguo, participa da bissexualidade e desempenhará sempre o papel de mediador. Que desça do céu à terra ou da terra aos infernos para mostrar o caminho da salvação, participa de duas naturezas: masculina e feminina, divina e humana.

De tal modo, a androginia e a dupla natureza sacro-terrena andam juntas pois a figura de Jesus é a própria ambiguidade, o que explica pois porque, enquanto Filha, Jesus é ao mesmo tempo Mãe. Por um lado, Jesus é a Mãe que nutre e guia, e a Filha, que se sacrifica e salva. Por outro Medeia, em mesma chave, é ao mesmo tempo a filha deserdada - motivo de seu sofrimento - e Mãe que deserda. Se Jesus é uma conjugação de símbolos femininos de acolhimento, Medeia é a tragédia materna da rejeição. E, nesse sentido, dialogam com as suas deusas-mãe Hécate/Maria.

Outra chave fundamental analógica é a tríplice natureza. Jesus é parte de uma trindade (Pai, Filho e Espirito Santo), que representa a natureza tríplice do Deus cristão. Porém, ao analisarmos Jesus mulher, pendemos para uma confusão da divindade Mãe com a mãe terrena, Maria, ela também uma divindade ${ }^{x}$, e nesse sentido buscamos a confluência da natureza tríplice não apenas na Trindade, mas na figura materna de Maria.

Aludiremos, para compreensão dessa dimensão tríplice, aos eventos ligados a Jesus. Os evangelhos citam tanto a presença de três mulheres na crucificação de Jesus, quanto a visita de três mulheres ao túmulo de Jesus, mesmo que não delimitem de modo claro quem seriam essas três. Esses grupos são chamados de Três Marias, e dizem respeito em geral, dentre outras possibilidades, à própria mãe de Jesus, a Maria Madalena e a Maria de Clopas ou Cleófas ${ }^{X 1}$. Se considerarmos a relação entre Maria e Hécate, podemos enxergar a mesma divisão de uma imagem divina feminina em três faces, relacionadas à filha-sacerdotisa.

Se Jesus é, portanto, em sua faceta masculina, filho da Deusa, falta-lhe ainda uma característica, como aponta Marquetti 
(2013, p. 284), que seria "fecundar a mãe". O filho é consorte, ao mesmo tempo, no rito pagão, porém é esperado que, no conceito cristão de relações entre os seres, o papel do sexo enquanto elemento fundamental de culto seja consideravelmente minimizado - por associação ao pecado original. No entanto, Marquetti observa que haveria a possibilidade de uma exceção pois, se considerarmos o ambiente dos textos apócrifos, nos quais Jesus (masculino) é consorte de outra muIher, Maria Madalena, temos um fechamento da razão tríplice. Marquetti aponta, assim, "o casamento de Jesus com Maria Madalena, a prostituta sagrada, imagem da nova Koré que substituiria Maria, a Deusa Mãe". Assim, tendo em vista a tripla face da Deusa, Madalena representa o traço sexual que desperta o oposto masculino da sacerdotisa. Jesus é uma figura que tem sua comunhão sexual negada pela tradição em prol de uma comunhão fraterna, ligada a imagem dos apóstolos e da humanidade, e se isso de certo modo via apagar traços do pecado de ordem sexual, por outro, reforça o traço feminino de Jesus, confirmando sua ambiguidade.

\section{Sistemas binomiais e triádicos: pequeno exercício SimbolísticoXII}

Interessante acrescentar à dimensão analógico-simbólica da imagem de Cristo que, tanto em seu nascimento quanto em sua morte, Jesus possui um trio de espectadores: Três magos/Três Marias. É mais um elemento na linha de simbologias ligadas ao número três associadas a Cristo: a Trindade Pai/Filho/ Espírito e sua versão feminina, os Três Reis Magos, as Três Marias e assim por diante. Nossa comparação com a tríplice Hécate para, de tal modo, aproximar Medeia e Cristo, nos conduz ao momento final deste ensaio: a compreensão da dimensão poética que representam essas personagens, no que diz respeito ao tópos oposto/complementar, do herói/anjo caído Orfeu-Lúcifer.

Quando apresentamos esse tópos, o resumimos em uma tabela, que apresentava a dinâmica da arquetipologia dos mythos do herói/anjo caído:

\begin{tabular}{|c|c|c|c|c|c|c|}
\hline \multicolumn{7}{|c|}{ O TOPOS DO HERÓI CAÍDO } \\
\hline & \multirow[b]{4}{*}{ Heróis } & Mitema a & & & ema $\mathbf{b}$ & \\
\hline & & \multirow[b]{3}{*}{ Heroísmo } & \multicolumn{4}{|c|}{ Queda } \\
\hline & & & \multicolumn{2}{|c|}{ Ação } & \multicolumn{2}{|c|}{ Movimento } \\
\hline & & & (i) o desejo & (i) o erro & (i') ascensão & (ii') queda \\
\hline \multirow{2}{*}{ mythos } & Orfeu & $\begin{array}{c}\text { Viagem } \\
\text { com os } \\
\text { Argonautas }\end{array}$ & O casamento & $\begin{array}{l}\text { Olhar } \\
\text { para trás }\end{array}$ & $\begin{array}{l}\text { Subir de volta } \\
\text { do Hades } \\
\text { para a } \\
\text { superfície }\end{array}$ & $\begin{array}{l}\text { Perde a amada } \\
\text { e é punido com } \\
\text { a morte por } \\
\text { esquartejamento }\end{array}$ \\
\hline & Lúcifer & $\begin{array}{c}\text { Anjo do } \\
\text { cortejo de Deus }\end{array}$ & $\begin{array}{c}\text { Assemelhar-se } \\
\text { a Deus }\end{array}$ & A soberba & $\begin{array}{l}\text { Desejar subir } \\
\text { ao "ponto } \\
\text { mais elevado } \\
\text { de Zafon" }\end{array}$ & $\begin{array}{l}\text { Jogado ao } \\
\text { abismo } \\
\text { por Deus }\end{array}$ \\
\hline
\end{tabular}


Há que se considerar que, se propomos um espelho dessa dinâmica, devemos encontrar um espelho do esquema e de suas principais constituições, iniciando pelos mitemas pois, quando propomos a dimensão poética dos tópoi, os propomos enquanto mythos, ou seja, narrativas. Nesse sentido, iremos introduzir uma dinâmica metodológica ainda aberta, dos sistemas binomiais e triádicos.

Em resumo, trabalhamos em modelos baseados em dois personagens que se opõem/completam, e cujo movimento em relação a outros dois personagens formam uma dinâmica criativa. Em primeiro lugar, há uma hierarquia, que é o binômio que identificamos originalmente, Orfeu-Medeia, e que é unido por uma tríade de elementos constitutivos, a saber, suas características identitárias de sacerdote, mago/feiticeira e Poeta. A partir daí, delimitamos o binômio que iria dialogar com aquele, no contexto da tradição ocidental de constituição de um modelo poético, Jesus-Lúcifer. Então, o sistema binomial dinâmico se constrói com a dupla representação do topos arquetipal poético, na constituição de um modelo de Poeta: Orfeu-Lúcifer/Medeia-Jesus. A título de organização, definiremos esses dois binômios respectivamente como catabático e ascensional, pela dimensão que os movimentos de queda/ascensão representam em sua constituição. Deles extrairemos, pelas narrativas (mythos), as possibilidades mitemáticas de composição de um ideal de Poeta. Foi o que fizemos, no outro texto, com Orfeu-Lúcifer.

O primeiro grande problema que surge na constituição do mythos para formulação do binômio ascensional é a falta de equivalência direta pois, considerando que Jesus é marcada fundamentalmente pela narrativa do nascimento-milagres-morte-ressurreição, e que o mythos de Medeia é viagem-traição/vingança-ascensão, não temos, para Medeia, narrativa equivalente ao nascimento. No caso do binômio catabático, o mythos é dividido em dois mitemas, Heroísmo (a) e Queda (b), e este último se subdivide em uma relação de causa (Ação) e Consequência (Movimento); essas duas, ainda, estão divididas em duas dinâmicas cada: desejo (i) e erro (ii) para Ação, ascensão (i') e queda(ii') para Movimento. Precisamos, assim, refletir se há possibilidade de estabelecer uma relação produtiva entre as duas personagens em, pelo mythos e seus mitemas, avaliar se seus elementos equivaleriam, para além dos já analisados campos simbólicos-alegóricos que as igualam enquanto mulher-estrangeira-feiticeira.

Assim, se nossa proposta é realizar uma equivalência elemento a elemento entre o mythos de cada figura referencial, podemos pensar na Identidade (a) como sendo o primeiro mitema, já que dela depende a relação entre ambas, além da Ascensão (b), o segundo mitema. Aqui criamos nosso mythos, para compreensão da relação entre Medeia e Jesus, a partir de dois mitemas:

- Mitema a: o mitema da Identidade, baseado nas características de gênero (i), origem (ii) e poder (iii);

- Mitema b: o mitema da Ascensão, baseado nos movimentos de traição (i) sacrifício (ii) e renascimento (iii).

Assim, temos o desenvolvimento do mythos que caracteriza o tópos da feiticeira sacrificada, que esquematizamos abaixo: 


\begin{tabular}{|c|c|c|c|c|c|c|c|}
\hline \multicolumn{8}{|c|}{ O TÓPOS DA FEITICEIRA SACRIFICADA } \\
\hline & \multirow{3}{*}{ Feiticeiras } & \multicolumn{3}{|c|}{ Mitema a } & \multicolumn{3}{|c|}{ Mitema b } \\
\hline & & \multicolumn{3}{|c|}{ Ação } & \multicolumn{3}{|c|}{ Movimento } \\
\hline & & $\begin{array}{c}\text { (i) } \\
\text { gênero }\end{array}$ & $\begin{array}{c}\text { (ii) } \\
\text { origem }\end{array}$ & $\begin{array}{l}\text { (i) } \\
\text { poder }\end{array}$ & $\begin{array}{c}\text { (i) } \\
\text { traição }\end{array}$ & $\begin{array}{c}\text { (ii) } \\
\text { sacrifício }\end{array}$ & $\begin{array}{c}\text { (iii) } \\
\text { renascimento }\end{array}$ \\
\hline \multirow[b]{2}{*}{ mythos } & Medeia & Mulher & $\begin{array}{l}\text { Vem da } \\
\text { Cólquida } \\
\text { a lolco }\end{array}$ & $\begin{array}{c}\text { Sacerdotisa } \\
\text { de Hécate, } \\
\text { feiticeira } \\
\text { (phármakoi) }\end{array}$ & Jasão & $\begin{array}{l}\text { Matar } \\
\text { os filhos }\end{array}$ & $\begin{array}{l}\text { Ascende } \\
\text { no carro } \\
\text { de Hélio }\end{array}$ \\
\hline & Jesus & $\begin{array}{l}\text { Andrógina/ } \\
\text { Bissexuada }\end{array}$ & $\begin{array}{c}\text { Nasce em } \\
\text { Belém, } \\
\text { fora da } \\
\text { terra de } \\
\text { seus pais }\end{array}$ & $\begin{array}{c}\text { Filha de } \\
\text { Deus e } \\
\text { Maria, } \\
\text { (milagres) }\end{array}$ & Judas & Crucificação & $\begin{array}{c}\text { Ressucita } \\
\text { ao terceiro } \\
\text { dia depois } \\
\text { de morta e } \\
\text { ascende } \\
\text { ao lado } \\
\text { de Deus }\end{array}$ \\
\hline
\end{tabular}

Fica claro, numa primeira leitura, que existe uma oposição/complementação entre um ambiente mitemático estático (a) e outro que representa uma série de movimentos (b). Se considerarmos uma dinâmica espelhada entre os dois binômios, deveríamos considerar reelaborar a proposta feita para o sistema anterior, do binômio catabático. E aí já caímos em outra dinâmica metodológica transversal, em que temos um desdobro de dimensões que não aplicamos objetivamente a Orfeu-Lúcifer: de identidade. No caso do binômio catabático, propomos, impõem-se sobre eles três identidades, também: homem-herói-rebelde. Porém, no caso do binômio ascensional, o ambiente identitário serve ao mythos como traço definidor muito mais marcante que a natureza heroica/ angelical. São os movimentos que determinam a lógica do topos do herói caído, pois a queda é parte fundamental da sua constituição, enquanto que a feiticeira é definida por categorias, digamos, mais estáticas, que envolvem sua identidade e um único movimento, de ascensão. Poderíamos, ainda, considerar o sacrifício como um movimento de queda, no qual ainda as feiticeiras se veem como seres abandonados à própria sorte e sofrem, mas não é, como no caso do binômio catabático, algo consequente de um erro. Os atos de desobediência têm papel fundamental na rebeldia como fator constituinte da persona no binômio catabático, enquanto que no caso do par Medeia-Jesus não temos o mesmo peso ${ }^{\mathrm{XIII}}$. Mesmo assim, assumimos o risco de reinterpretar o sistema, renomeando o Mitema $b$ do binômio catabático como "Catábase", e mantendo a dinâmica "ação x movimento" do primeiro modelo, mas mudando o segundo elemento para "reação", para criar um efeito simbólico. Inserimos no tópos a mesma coluna "identidade" do binômio ascensional, e consideramos a construção do Mitema a da mesma forma: gênero, origem e poder, como correspondentes alegóricos de homem-herói-rebelde. 


\begin{tabular}{|c|c|c|c|c|c|c|c|c|}
\hline \multicolumn{9}{|c|}{ O TOPOS DO HERÓI CAÍDO } \\
\hline & \multirow{4}{*}{ Heróis } & \multicolumn{3}{|c|}{ Mitema a } & \multicolumn{4}{|c|}{ Mitema b } \\
\hline & & \multirow{2}{*}{\multicolumn{3}{|c|}{ Identidade }} & \multicolumn{4}{|c|}{ Catábase } \\
\hline & & & & & \multicolumn{2}{|l|}{ Ação } & \multicolumn{2}{|c|}{ Reação } \\
\hline & & $\begin{array}{l}\text { (i) } \\
\text { gênero }\end{array}$ & $\begin{array}{l}\text { (ii) } \\
\text { origem }\end{array}$ & $\begin{array}{l}\text { (iii) } \\
\text { poder }\end{array}$ & $\begin{array}{c}\text { (i) } \\
\text { o desejo }\end{array}$ & $\begin{array}{c}\text { (ii) } \\
\text { o erro }\end{array}$ & $\begin{array}{c}\text { (i’) } \\
\text { ascensão }\end{array}$ & $\begin{array}{l}\text { (ii') } \\
\text { queda }\end{array}$ \\
\hline \multirow{2}{*}{ mythos } & Orfeu & homem & $\begin{array}{l}\text { Herói, } \\
\text { argonautaxiv, } \\
\text { filho de Caliope } \\
\text { e sacerdote } \\
\text { de Apolo }\end{array}$ & $\begin{array}{c}\text { Música e } \\
\text { encantamento }\end{array}$ & $\begin{array}{c}0 \\
\text { casamento }\end{array}$ & $\begin{array}{c}\text { Olhar } \\
\text { para trás }\end{array}$ & $\begin{array}{c}\text { Subir } \\
\text { de volta } \\
\text { do Hades } \\
\text { para a } \\
\text { superfície }\end{array}$ & $\begin{array}{c}\text { Perde } \\
\text { a amada } \\
\text { e é punido } \\
\text { com a } \\
\text { morte por } \\
\text { esquartejamento }\end{array}$ \\
\hline & Lúcifer & homem & $\begin{array}{l}\text { Anjo do } \\
\text { cortejo } \\
\text { de Deus }\end{array}$ & $\begin{array}{l}\text { Persuasão } \\
\text { e tentaçãaoxv }\end{array}$ & $\begin{array}{c}\text { Assemelhar-se } \\
\text { a Deus }\end{array}$ & $\begin{array}{c}\text { A } \\
\text { soberba }\end{array}$ & $\begin{array}{c}\text { Desejar } \\
\text { subir ao } \\
\text { "ponto mais } \\
\text { elevado } \\
\text { de Zafon" }\end{array}$ & $\begin{array}{c}\text { Jogado } \\
\text { ao abismo } \\
\text { por Deus }\end{array}$ \\
\hline
\end{tabular}

Assim, por fim, o que encontramos são dois tópoi exemplificados em binômios arquetípicos - obviamente esses tópoi remetem a arquétipos - e organizados em sistemas dinâmicos que funcionam a partir de mythos. Cada parte do binômio, as personas fazem parte de um sintagma nominal, a saber, um substantivo (Heróis/Feiticeiras) e um adjetivo (caído/sacrificado) cujo desenvolvimento se dá em dois mitemas que se subdividem de maneira razoavelmente espelhada.

\section{Considerações finais}

Sem querer correr o risco de tornar nossa metodologia mecanicista, delineamos os esquemas anteriores para a apreensão mais sistemática das reflexões. Não significa, no entanto, que fechamos as possibilidades de análise à mera aplicabilidade do modelo que desenhamos. Não consideramos aqui poesia religiosa ou de tema associado aos tópoi como forma exclusiva para a análise, masuma aplicabilidade hermenêutica ampla da reflexão. Os sujeitos Medeia-Jesus - bem como o par Orfeu-Lúcifer -, enquanto personificações de um tópos, são o ponto de partida para a amplitude infinita de símbolos que se materializam verbalmente enquanto sintagmas em diversas obras, e apontam para a natureza arquetípica da relação poesia-magia-religião e, em certa medida, ao fluir do imaginário poético pagão para dentro do cristianismo.

É claro que, de tal modo, se não queremos confinar os sistemas a uma chave dicotômica masculino/feminino, deveríamos realizar o cruzamento das figuras, buscando o mesmo tipo de leitu- 
ra comparativa simbólica para os pares Jesus-Orfeu, Medeia-Lúcifer, Medeia-Orfeu e, por fim Jesus-Lúcifer. Como o texto apresentado faz parte de um trabaIho maior, desenvolvido durante estágio de pós-doutoramento, que propõe uma perspectiva de análise que intitulamos Simbolística, e não passa de uma experiência alegórico-exegética de poesia, restringimos por ora a análise aos binômios propostos, mas não fechamos a reflexão. Pelo contrário: abrimos aqui espaço para uma infinita meditação acerca das imagens que coligimos, sem o receio de que pareçamos ter circulado o assunto de maneira pouco objetiva - em verdade, se o fizemos, obtivemos sucesso. No mais, em uma era de violência e incompreensão cada vez maiores no que diz respeito às dinâmicas de gênero dentro e fora da arte, preferimos encerrar este texto com o fechamento de O evangelho segundo Jesus, Rainha do Céu, de Jo Clifford:

Não nos deixeis, não nos deixeis jamais esquecer, que ele é ela

e ela é ele

e nós somos eles

e eles somos nós

e assim será

para sempre

para todo

todo

o sempre

Amém.

\section{Bibliografia}

ANDRADE, C. D. de. Alguma poesia. São PauIo: Companhia das Letras, 2013. BARBOSA, Tereza Virgínia Ribeiro. Uma mulher vestida de sol: Medeia e a virgem-mãe Maria. Arquivo Maaravi: Revista Digital de Estudos Judaicos da UFMG. Belo Horizonte, v. 7, n. 12, mar. 2013, p. 170-179. Disponível em: http://www. periodicos.letras.ufmg.br/index.php/maaravi/ article/viewFile/4686/4396. Último acesso: 11 de julho de 2017.

BIBLIA HEBRAICA STUTTGARTENSIA. K. Elliger, W. Rudolph (ed.), Stuttgart: Deutsche Bibelgesellschaft, 1997. Disponível em: http://www. academic-bible.com/en/online-bibles/biblia-hebraica-stuttgartensia-bhs/read-the-bible-text. Último Acesso: 29 de julho de 2017.

BYNUM, Caroline Walke. Jesus as Mother and Abbot as Mother: Some Themes in Twelfth-Century Cistercian Writing. The Harvard Theological Review, Vol. 70, No. 3/4. Cambridge University Press on behalf of the Harvard Divinity School, Jul. - Out., 1977, p. 257-284. Disponível: http:// www.jstor.org/stable/1509631. Último acesso: 11 de julho de 2017.

DANTAS, Carolina. "Representei a dor que sentimos", diz transexual 'crucificada' na Parada Gay". G1. São Paulo, Junho de 2015. Disponível em: http://g1.globo.com/sao-paulo/noticia/2015/06/ representei-dor-que-sentimos-diz-transexual-crucificada-na-parada-gay.html. Último acesso: 11 de julho de 2017.

DECLERCQ, Marie. "Jesus Cristo foi o primeiro trans", diz a $1^{a}$ pastora transgênera da América Latina". Vice Brasil. São Paulo, Junho de 2017. Disponível em: https://www.vice.com/pt_br/ article/8xa943/jesus-cristo-foi-o-primeiro-trans-diz-a-1a-pastora-transgenera-da-america-latina. Último acesso: 11 de julho de 2017.

DINIZ, Fábio Gerônimo Mota. A Catábase de Orfeu e a queda de Lúcifer: a identidade do Poeta como um herói caído. Revista Texto Poético. Vol. 18 (1º sem-2015), pp. 209-236. Disponível em: http://revistatextopoetico.com.br/index.php/ rtp/article/view/410/323. Último acesso em 11 de julho de 2017.

DINIZ, Fábio Gerônimo Mota. A religião, a magia e o canto de Orfeu na Argonáutica de Apolônio de Rodes. Araraquara: Tese de Doutorado/ Programa de PósGraduaçãoem Estudos Lite- 
rários da FCLAr, 2014. Disponível em: http:// portal.fclar.unesp.br/posestlit/teses/Fabio_Geronimo_Mota_Diniz_DO.pdf. Último acesso em: 10 jan. 2015.

DURAND, Gilbert. As estruturas antropológicas do imaginário: introdução à arquetipologia geral. Tradução de Hélder Godinho. São Paulo: Martins Fontes, 2012.

DURAZZO, Leandro Marques. Gestação de Orfeu: profecia e transcendência na poesia de Jorge de Lima. Rio de Janeiro: Editora Multifoco, 2013.

EURÍPEDES. Medeia. Edição bilíngue. Tradução e notas de Trajano Vieira. São Paulo: Ed. 34, 2010.

JEROME St. Vulgate Bible. Ed. Bible Foundation and On-Line Book Initiative. Disponível em: http:// www.perseus.tufts.edu/hopper/text?doc=urn:cts :greekLit:tlg0527.tlg001.perseuslat1:1.1. Último acesso em 12 de junho de 2015.

KELLY, H, A. Satã: uma Biografia. Tradução de Renato Rezende. São Paulo: Globo, 2008.

MARQUETTI, Flávia Regina. Da sedução e outros perigos: o mito da Deusa Mãe. São Paulo: Editora Unesp, 2013.

OLIVEIRA, F. R. Introdução. In: EURÍPIDES. Medeia. Trad., introd. e notas: Flávio Ribeiro de Oliveira. São Paulo: Odysseus Editora, 2006. p. 13-25.

WESTCOTT, D. D.,Brooke Foss; HORT, D.D,Fenton John Anthony (ed.). Testament in the original Greek. Nova York: Harper \& Brothers, Franklin Square,1885. Disponível em: http://data. perseus.org/citations/urn:cts:greekLit:tlg0031. tlg001.perseus-grc1:27.46. Último acesso 29 de julho de 2017.
I Fábio Gerônimo Mota Diniz. Doutor em Estudos Literários pela Universidade Estadual Paulista Julio de Mesquita / UNESP (SP, Brasil).

II Fontes consultadas observam que há uma diferença entre o texto de Marcos e Matheus, especialmente na transcrição de 'E $\lambda \omega$ í/Eloí, que seria a forma encontrada em Marcos, em contraponto à encontrada em Mateus, 'H $\mathrm{\lambda} i / E l i ́$. Como nossa referência para esse texto foi a versão presente na plataforma Perseus - que inclui os textos em latim a partir da Vulgata de São Jerônimo e a edição em grego recolhida por Westcott e Hort (1885) -, e nesta não é notada a diferença, mantivemos como se encontra no texto do Evangelho segundo São Matheus da plataforma. Ademais, a diferença não interfere semanticamente no trecho.

III Usamos para o texto hebraico a Biblia Hebraica Stuttgartensis, referência disponibilizada online pela German Bible Society. Cf. Referências.

IV A comparação que opõe Medeia e Orfeu deriva de nossa análise do poema épico helenístico Argonáutica, realizada em DINIZ, 2015.

V Como observamos em DINIZ, 2016.

VI Durazzo (2012, p. 149-150) comenta sobre essa percepção iconográfica de Cristo, em comparação com Orfeu, percebendo igualmente sua androginia.

VII "First of all, the images assume certain sexual stereotypes-that is, they show that, to these religious writers, certain personality characteristics were seen as female and certain characteristics as male. Throughout these texts, gentleness, compassion, tenderness, emotionality and love, nurturing, and security are labeled female (or "maternal"); authority, judgment, command, strictness, and discipline are labeled male (or "paternal"); instruction, fertility, and creativity are associated with both sexes (either as begetting or as conceiving). [...] Breasts and nurturing are more frequent images in this literature conceiving and giving birth. And where birth and the womb dominant images, the mother is usually described as one who and carries the child in her womb, not as one who ejects the child world, suffering pain and possibly death in order to give life. Conceiving and giving birth, like suckling, are thus images primarily of return or union, security, protection, dependence or incorporation, images of alienation, sacrifice, or emergence in the sense of separation. References to God as mother usually occur, not in the context castigation of sinners or elaboration of the gulf between human divine, but rather as part of a general picture of the believer beginner, totally dependent on a loving and tender God". Tradução do autor. 
VIII Tradução de Trajano Vieira. Cf. Referências Bibliográficas.

IX et adorabunt eum omnes reges omnes gentes servient ei. Tradução do autor. Cf. JEROME St.

X Poderíamos expandir essa interpretação: Jesus é fruto de uma relação entre duas mulheres, duas deusas, o que explicaria talvez a virgindade de Maria, pois não há penetração.

XI Maria de Clopas é uma figura associada a Cristo como sua tia, irmã de Maria. É uma figura complexa e sobre a qual não nos deteremos pois não tem, em si, uma dimensão significativa no diálogo que estabelecemos entre as imagens de Hécate e Maria, a não ser permitir que a tríplice se mantenha.

XII A Simbolística é uma proposta originada de projeto de pesquisa desenvolvido como parte do estágio de pós-doutoramento, sob financiamento pelo PNPD (CAPES), junto ao programa de Pós- Graduação em Estudos Literários da Faculdade de Ciências e Letras da Unesp de Araraquara. O projeto constitui uma proposta de nova possibilidade de leitura do universo artístico que visa, pela tentativa de conjunção entre simbologia e holística, elaborar metodologias arquetipológicas de análise, baseadas principalmente nas teorias de Gilbert Durand, Gaston Bachelard e Carl Gustav Jung, dentre outros. O presente texto dialoga com o trabalho, ainda não publicado, Simbolística Parte I - Por uma teoria do símbolo poético.

XIII A desobediência de Medeia em relação a seu pai, ao aliar-se ao estrangeiro Jasão, poderia ser levantada como argumento contrário à nossa hipótese, mas o sacrifício e dor de Medeia não se dão como frutos de sua desobediência, mas como consequências da traição e como parte de um destino. Além disso, se assumirmos a narrativa como apresentada por Apolônio de Rodes, o amor de Medeia é vítima do ardil divino de Hera e Afrodite, que querem que Jasão tenha sucesso em sua empreitada. Ela não desobedece voluntariamente, e por isso sofre pelo amor.

XIV Reduzimos "Viagem com os Argonautas" para "argonauta", pois aqui mais importa a identidade que a viagem, mesmo que haja a possibilidade de se pensar a dinâmica ida x volta na construção específica de Orfeu.

XV Consideramos a persuasão como poder de Lúcifer tendo em vista tanto a relação deste poder com a música de Orfeu, capaz de encantar os seres e interferir diretamente no seu estado emocional e em suas ações, quanto por considerarmos este como sendo a principal ação dele enquanto "adversário". Claro que o sistema funciona partindo do imaginário cristão moderno, ou seja, se o considerarmos como uma figura unitária satânica, que agrega a serpente que tenta Adão e Eva, o anjo que quer se assemeIhar a Deus e aquele que tenta a Jesus no deserto, apenas para selecionar algumas narrativas exemplares. Esses poderes se relacionam com o status "rebelde" de ambos. 